\title{
Sciendo
}

\section{Georgia on its Path to Europeanisation: Academic Cooperation}

\author{
Archil Chochia \\ Tanel Kerikmäe \\ Department of Law, \\ Tallinn University of Technology \\ Akadeemia tee 3, \\ Tallinn 12618, Estonia \\ Email: archil.chochia@taltech.ee \\ Email: tanel.kerikmae@taltech.ee
}

TalTech Journal of European Studies (TJES) has recently undergone a change in its focus, and also the name of the journal has changed from the Baltic Journal of European Studies to the current one. The journal's scope has changed accordingly, and now encompasses digitalisation and technology implementation, and their impact on the social, legal, political, economic and cultural domains in the European Union and its Member States.

There is no clarity on how legal and ethical frameworks could effectively regulate human-machine interaction, what should be the normative and institutional components of such frameworks and which legal categories could help build a functional governance model. The use of machine-learning, big data and other artificial intelligence technologies has become an essential element of the competitiveness of digital systems; however, the public trust in "black box" algorithms is still too low to effectively implement these in the public sector. Besides, decisions made by "black box" mechanisms do not yet comply with the requirements of legal certainty. The EU has issued a number of strategic guidelines to urge the Member States to efficiently regulate AI, and make an effort to balance the protection of human rights and democratic values along with the successful adoption of $\mathrm{AI}$ in the public sphere (Kerikmäe \& Pärn-Lee, 2020). The new scope of this journal aims to boost academic discussion on the comprehensive legal framework to limit the loss of human control over technologies while increasing the capacity of public and private services, by performing an in-depth analysis of EU regulations, legal theory and practices of states (Kerikmäe et al., 2018). 
A study of the social, ethical, and legal consequences of the wide-scale employment of AI-enabled technologies requires an interdisciplinary perspective. This is a view aligned with Lessig's (1999) or Hirschl's (2014) methodological understanding of the study of norm creation and law as a living entity, which is subjective in nature and formed by various societal forces. Laws are not axiomatic but evolve in time-in Savigny's words, "organically"-in the process of social discourse, facilitated by prudent and forward-looking actions by the parliament (legislator), the government (executive), and the society as a whole. The research articles published in TJES will address the social, ethical, and legal aspects of such discourse in the new setting, created by AI. What sets the question of a legal framework for AI apart from that of other, previous, technology-related legislative work is the wide variety of areas potentially affected by technological development. Among the most interesting questions are those that we broadly call philosophical questions about what the use of AI means for society. These are the questions regarding whether, why or why not, how, within what limits, AI should be used. The first global attempt to seek a common standard for the key phenomenon today-the UNESCO Draft Text of Recommendation on the Ethics of Artificial Intelligence also emphasises regional cooperation. The draft states that

economic competition is taking place within and between states and also between multinational companies, potentially causing AI strategies and regulatory frameworks to be focused on national and commercial interests, while global cooperation is needed to address the challenges that AI brings in a diversity and interconnectivity of cultures and ethical systems, and to mitigate potential misuse. (UNESCO, 2020)

Following the recent changes, our journal's new focus continues to take account of the aspirations, vulnerabilities and capacities of different countries and regions and the related issues. Aside from the indicated changes, TJES will continue the existing tradition of publishing special issues with a thematic or regional focus (see 2019/3, 2019/2, 2018/2, 2017/1; Vernygora et al., 2019; Chochia \& Kerikmäe, 2018; Shumilo et al., 2019).

TalTech Law School (TLS) has a long history of cooperation with their Georgian partners, including public institutions, local universities and organisations. During these years more than 100 Georgian students have studied at TLS, and many of our alumni are currently working in public and private sectors in Georgia. The universities have been cooperating in research and development activities, including curricula development and 
supervision of doctoral dissertations. TLS has hosted two Jean Monnet conferences on EU Eastern Partnership-in September 2015 in Georgia and in February 2016 in Estonia-with the involvement of representatives of these Georgian schools. Furthermore, Professor Tanel Kerikmäe and Dr. Archil Chochia recently published the book Political and Legal Perspectives of the EU Eastern Partnership Policy (Kerikmäe \& Chochia, 2016). TLS has been implementing several projects in Georgia, including Horizon2020 projects and projects funded by Estonian Ministry of Foreign Affairs within the framework of its Development Cooperation Programme.

According to Georgian Government's Strategy 2014-2017 on information and communication related to Euro-integration (no. 1237), it is vital for Georgia to inform its citizens about the country's European integration process, as well as to educate ordinary citizens and officials in EU-related fields. It is very important for Georgian partners to have access to additional training in the mentioned fields and up-to-date materials, as well as the possibility to share experience and establish long-term partnerships with European colleagues (Kerikmäe et al., 2014; Chochia \& Popjanevski, 2016; Chochia \& Kerikmäe, 2018). Georgia's geopolitical location and its historical connectivity between Eastern and Western markets have always been the main driving force for economic development (Charaia et al., 2018). Georgia has achieved sizable progress in its goal to become an ICT-driven nation, implementing several reforms and engaging in many cooperation projects with leading countries in the field. Estonia, as one of the flagship Member States in the field, has been closely cooperating with Georgia, with several completed and ongoing projects supporting the country to strengthen its e-Governance (Napetvaridze \& Chochia, 2019). Accordingly, the process has to be reflected when updating study programmes and setting-up new research directions in higher education institutions. The most developed Eastern Partnership country has great visions on e-Governance built on European values; however, the feedback from Georgian colleagues suggests that there is a lack of cooperation between Georgian and Estonian scholars in the field of EU studies in general. Therefore, this journal issue serves the purpose of promoting research cooperation between Georgia and the EU. 


\section{References}

Charaia, V.; Chochia, A. \& Lashkhi, M. (2018), 'Caucasus 3 plus Baltic 3 and economic cooperation with China,' Baltic Journal of European Studies, vol. 8, no. 2, pp. 44-64. https://doi.org/10.1515/bjes-2018-0015

Chochia, A. \& Popjanevski, J. (2016), 'Change of power and its influence on country's Europeanization process. Case study: Georgia,' in T. Kerikmäe \& A. Chochia (eds.) Political and Legal Perspectives of the EU Eastern Partnership Policy, Cham: Springer International Publishing, pp. 197-210. https://doi.org/10.1007/978-3-319-27383-9_13

Chochia, A. \& Kerikmäe, T. (2018), 'Digital single market as an element in EUGeorgian cooperation,' Baltic Journal of European Studies, vol. 8, no. 2, pp. 3-6. https://doi.org/10.1515/bjes-2018-0012

Hirschl, R. (2014), Comparative Matters: The Renaissance of Comparative Constitutional Law, Oxford: Oxford University Press.

Kerikmäe, T.; Nyman-Metcalf, K.; Gabelaia, D. \& Chochia, A. (2014), 'Cooperation of post-Soviets with the aim of not being "post" and "Soviets",' in N. Šišková (ed.) From Eastern Partnership to the Association. The Legal and Political Analysis, Cambridge: Cambridge Scholars Publishing, pp. 144-159.

Kerikmäe, T. \& Chochia, A., eds. (2016), Political and Legal Perspectives of the EU Eastern Partnership Policy, Cham: Springer International Publishing. https://doi.org/10.1007/978-3-319-27383-9

Kerikmäe, T.; Hoffmann, T. \& Chochia, A. (2018), 'Legal technology for law firms: determining roadmaps for innovation,' Croatian International Relations Review, vol. 24, no. 81, pp. 91-112. https://doi.org/10.2478/cirr-2018-0005

Kerikmäe, T. \& Pärn-Lee, E. (2020), 'Legal dilemmas of Estonian artificial intelligence strategy: in between of e-society and global race,' AI \& Society. https://doi.org/10.1007/s00146-020-01009-8

Lessig, L. (1999), Code: And Other Laws of Cyberspace, Basic Books: New York.

Napetvaridze, V. \& Chochia, A. (2019), 'Cybersecurity in the making-policy and law: a case study of Georgia,' InternationaI and Comparative Law Review, vol. 19, no. 2, pp. 155-180. https://doi.org/10.2478/iclr-2019-0019

Shumilo, O.; Kerikmäe, T. \& Chochia, A. (2019), 'Restrictions of Russian internet resources in Ukraine: national security, censorship or both?' Baltic Journal of European Studies, vol. 9, no. 3, pp. 82-95. https://doi.org/10.1515/bjes-2019-0023

UNESCO (2020), First Version of a Draft Text of a Recommendation on the Ethics of Artificial Intelligence, SHS/BIO/AHEG-AI/2020/4REV., 15.5.2020.

Vernygora, V.; Holland, M.; Chaban, N. \& Kerikmäe, T. (2019), 'The Asian experience for Europe: new perspectives,' Baltic Journal of European Studies, vol. 9, no. 2, pp. 3-5. https://doi.org/10.1515/bjes-2019-0010 